\title{
Biological Activity of Annona muricata Seed Extracts
}

\author{
Hoe,P.K., Yiu*,P.H., Ee ${ }^{\text {a }, G . C . L ., ~ W o n g, S . C ., ~ R a j a n, A . ~ a n d ~ B o n g, C . F . J . ~}$
}

Faculty of Agriculture and Food Science, Universiti Putra Malaysia Bintulu Campus, Nyabau Road, 97000

Bintulu, Sarawak, Malaysia

${ }^{a}$ Department of Chemistry, Faculty of Science, Universiti Putra Malaysia, 43400 Serdang, Selangor Darul

Ehsan, Malaysia

*yiuph@btu.upm.edu.my (Corresponding author)

Received on $16^{\text {th }}$ April 2009, accepted in revised form $21^{\text {st }}$ July 2010

\begin{abstract}
A study was conducted to assess the biological activity of Annona muricata hexane, methanol and chloroform seed extracts. Both the hexane and methanol extracts showed moderate larvicidal activity against the Aedes aegypti larvae while the chloroform extract exhibited strong larvicidal property with an $\mathrm{LC}_{50}$ value of $0.9005 \mu \mathrm{g} / \mathrm{ml}$ and an $\mathrm{LC}_{90}$ value of $6.1776 \mu \mathrm{g} / \mathrm{ml}$. Fraction $44 \mathrm{~b}$ and $45 \mathrm{~b}$ of the chloroform extracts were very toxic towards mosquito larvae with $\mathrm{LC}_{50}$ values of 0.7460 and $1.0402 \mu \mathrm{g} / \mathrm{ml}$, respectively. Identification of bioactive compounds revealed the presence of solamin, an acetogenin. From the cytotoxic assay against brine shrimp (Artemia salina), the methanol extract showed high toxicity with an $\mathrm{LC}_{50}$ value of $11.8823 \mu \mathrm{g} / \mathrm{ml}$. The results suggest potential application of the extracts in insecticidal formulations.
\end{abstract}

\begin{abstract}
ABSTRAK Satu kajian aktiviti biologi telah dijalankan pada ekstrak-ekstrak heksana, methanol dan klorofom biji Annona muricata. Ekstrak-ekstrak heksana dan methanol menunjukkan aktiviti larvisidal sederhana terhadap larva Aedes aegypti manakala, ekstrak klorofom mempamerkan sifat larvisidal yang kuat dengan nilai $\mathrm{LC}_{50} 0.9005 \mu \mathrm{g} / \mathrm{ml}$ dan $\mathrm{LC}_{90} 6.1776 \mu \mathrm{g} / \mathrm{ml}$. Fraksi $44 \mathrm{~b}$ dan $45 \mathrm{~b}$ ekstrak klorofom sangat toksik dengan nilai $\mathrm{LC}_{50} 0.7460$ dan $1.0402 \mu \mathrm{g} / \mathrm{ml}$ masing-masing. Kewujudan sebatian bio-aktif solamin, sejenis acetogenin telah dikenali-pasti. Dalam ujian citotoksik pada udang laut (Artemia salina), ekstrak metanol menunjukkan ketoksikan tinggi dengan nilai $\mathrm{LC}_{50} 11.8823 \mu \mathrm{g} / \mathrm{ml}$. Hasil kajian mencadangkan ekstrak berpotensi dalam formulasi-formulasi racun serangga.
\end{abstract}

(Keywords: Annona muricata, seed extracts, insecticidal, solamin)

\section{INTRODUCTION}

Pesticides are an integral part of modern agriculture. However, excessive and nonjudicious use has not only resulted in environment pollution, but also developed resistance in several pests, caused pest resurgence and adversely affected beneficial organisms like honeybee, pollinators and natural enemies like parasites and predators. This has led to recent trends in environment and health consciousness, and there are efforts to replace synthetic insecticides with natural components collectively known as "green pesticides". The emphasis in "green pesticides" is the shift from insect kill to insect control. It is estimated that by the year 2010 about 20-30 percent of synthetic pesticides will be replaced by biorational agents.

The members of the Annonaceae family are not foreign in the search for new bioactive compounds as this family has a number of compounds that have been identified for their cytotoxic and pesticidal properties. The family Annonaceae is one of the important families in the tropical lowland forest in the continents of Asia, Africa and America with 130 genera and over 2000 identified species [1,2]. According to Abdul Hamid (1993) [3], Peninsular Malaysia habitats 38 genera and 198 native and 5 cultivated species of which $2 / 3$ are trees and $1 / 3$ are climbers. The economic value [1] of Annonaceae family is not important till early $21^{\text {st }}$ century. Most taxa are understorey trees reaching to a maximum height of $20 \mathrm{~m}$ except for Annona genus like Annona reticulate (custard apple), Annona muricata (soursop) and few others more $[2,4,5]$.

Alali et al. [6] reviewed Annonaceae acetogenins which are a unique class of natural compounds with a wide variety of biological activity. Uvaricin is the first Annonaceae acetogenin that was discovered in 1982. Since then, the Annonaceaeous acetogenins are now one of the most rapidly growing classes of new natural products and offer exciting anthelmintic, antitumor, antimalarial, antimicrobial, antiprotozoal, and pesticidal activities and holds special promise for new chemotypes as antitumor and pesticidal agents. Some of the Annonaceous acetogenins compounds are bis-tetrahydrofuran acetogenin with C-28/C-29 vicinal diol, spinencin, annoglaxin, 27-hydroxy bullatacin, 
bullatacinore, (2,4-cis and trans)-32hydroxybullatacinone, (2,4-cis and trans)-31hydroxybullatacinone, coriadienin, coriaheptocins and (2,4-cis and trans)-mosnone A [7-13].

\section{MATERIALS AND METHODS}

\section{Seed extraction}

The seeds of Annona muricata were collected from different areas in Malaysia. The seeds were pooled together, air-dried before being ground into fine powder at room temperature. The powder was weighed (approximately $2.0 \mathrm{~kg}$ ) and extracted successively with n-hexane (Merck HPLC grade) three times after agitation for 48 hours on a orbital shaker.

The hexane extracts were then filtered, combined and then evaporated to dryness under reduced pressure at $40^{\circ} \mathrm{C}$ in a rotary evaporator. The hexane extract weighing $414.31 \mathrm{~g}$ was a thick yellowish oil. The filtered seed residues were then extracted again by chloroform (Merck HPLC grade) using the same procedure. The chloroform extract was a dark brownish coloured oily residue with a yield of $56.73 \mathrm{~g}$.

Finally, the filtered seed residues were then extracted with methanol (Merck HPLC grade) using the same method as above. The methanol extracts was a dark brownish coloured oily residue with a yield of $40.04 \mathrm{~g}$.

\section{Larvicidal assay}

The bioassay tests for Aedes aegypti larvae as recommended by WHO, were used to investigate the larvicidal activity of samples [14]. A standard stock solution of 10000ppm $(10000 \mathrm{~g} / \mathrm{ml})$ was prepared by dissolving $0.1 \mathrm{~g}$ of extract in $10 \mathrm{ml}$ of absolute ethanol. A range test solution was made by pipetting a sample of stock solution $(0.25 \mathrm{ml}, 0.5 \mathrm{ml}$ and $0.75 \mathrm{ml})$ into $25 \mathrm{ml}$ of dechlorinated water in glass containers. A control was prepared by using $0.75 \mathrm{ml}$ of absolute ethanol in chlorine free water.

Ten late third instar mosquito larvae were introduced to each glass by a dropper. The test sample was made up to $50 \mathrm{ml}$ with chlorine free water. A little larvae food (roasted chicken liver) was then added. The mortality of the mosquito larvae was counted after 24 hours.

A series of five different concentrations were prepared in duplicate to obtain $\mathrm{LC}_{50}$ values. The results were analysed using Probit Analysis Programme.

\section{Cytotoxicity assay}

The Artemia salina eggs were hatched 48 hours prior to the experiment. Seawater was filled to about $1000 \mathrm{ml}$ and $0.5 \mathrm{~g}$ of Artemia salina eggs were poured into the beaker of seawater. The beaker was aerated using the aerator to provide oxygen for the shrimps. The stock solution of 1000, 100, 10 and 1ppm were prepared each respectively diluted with its own eluting solvent. Ten shrimps were pipetted into each concentration in triplicate. The percent of mortality of the brine shrimps was counted for every concentration to determine $\mathrm{LC}_{50}$ (lethal concentration), after 24 hours. The results were analysed using Probit Analysis Programme [15].

\section{Antimicrobial activity}

Four microorganisms, Listeria monocytogenes, Vibrio parahaemolylicus, Escherichia coli and Pseudomonas aeruginosa were inoculated in the nutrient broth (Merck) at $37.5^{\circ} \mathrm{C}$ overnight. The microorganisms were then cultured on the nutrient agar (Merck) in a triplicate number for each microorganism respectively. The antimicrobial activity was qualitatively determined by a modified disc diffusion method [16].

Sterile discs $(6 \mathrm{~mm}$ in diameter $)$ were impregnated with different concentrations of the solvent extracts and placed on the inoculated agar. Ciprofloxacin was used as the positive control and eluting solvents as negative control. The inoculated plates were then, incubated at $37.5^{\circ} \mathrm{C}$ for 24 hour. The image of the inhibition zone was captured using the Alpha imager and measured. Antimicrobial activity was evaluated by measuring the zone of inhibition $(\mathrm{mm})$ against the microorganisms.

\section{RESULTS AND DISCUSSION}

\section{Larvicidal activity}

The hexane, chloroform and methanol extracts of Annona muricata were tested for larvicidal activity [17]. Table 1 shows that $\mathrm{LC}_{50}$ and $\mathrm{LC}_{90}$ values of the hexane extracts were 122.7713 and $307.3403 \mathrm{~g} / \mathrm{ml}$, respectively. The larvae of Aedes aegypti were very susceptible to the chloroform extract with an $\mathrm{LC}_{50}$ of $0.9005 \mathrm{~g} / \mathrm{ml}$ and $\mathrm{LC}_{90}$ of $6.1776 \mathrm{~g} / \mathrm{ml}$.

For the methanol extract, the toxicity was moderate with $\mathrm{LC}_{50}$ and $\mathrm{LC}_{90}$ values of 85.9151 and $1519.1490 \mathrm{~g} / \mathrm{ml}$, respectively. The chloroform extract of Annona muricata had the highest potency among all the extracts, followed by the methanol and the hexane extracts. 
Table 1: Larvicidal activity of Annona muricata seed extracts in different solvent systems.

\begin{tabular}{lll}
\hline Solvent system & $\mathrm{LC}_{50}(\mathrm{~g} / \mathrm{ml})$ & $\mathrm{LC}_{90}(\mathrm{~g} / \mathrm{ml})$ \\
\hline Hexane & 122.7713 & 307.3403 \\
Chloroform & 0.9005 & 6.1776 \\
Methanol & 85.9151 & 1519.1490 \\
\hline
\end{tabular}

The bioactive compound of Annona muricata was found mostly in the chloroform and methanol extracts, indicating a medium to high polarity compound. This group of acetogenin is commonly found among the members of Annonaceae [6].

\section{Isolation of bioactive compound}

The crude extracts were fractionated using column chromatography over a silica gel column using chloroform-methanol mixtures of increasing polarity as eluting solvent. The resulting fractions were tested for larvicidal $\begin{array}{lll}\text { activity } & \text { (Table }\end{array}$

Table 2: Larvicidal activity of chloroform fractions and active compound group present.

\begin{tabular}{|c|c|c|c|c|c|}
\hline $\begin{array}{l}\text { Chloroform } \\
\text { Fraction }\end{array}$ & $\begin{array}{c}\% \text { Mortality at } \\
50 \mathrm{~g} / \mathrm{ml}\end{array}$ & Bioactivity & $\mathrm{LC}_{50}(\mathrm{~g} / \mathrm{ml})$ & $\mathrm{LC}_{90}(\mathrm{~g} / \mathrm{ml})$ & $\begin{array}{l}\text { *Active } \\
\text { group }\end{array}$ \\
\hline $2 \mathrm{~b}(1 \sim 3)$ & 0.00 & Not active & - & - & - \\
\hline $4 \mathrm{~b}$ & 42.50 & Not active & - & - & - \\
\hline $5 b$ & 35.00 & Not active & - & - & - \\
\hline $6 \mathrm{~b}(6 \sim 8)$ & 35.00 & Not active & - & - & - \\
\hline $9 \mathrm{~b} 1(9 \sim 10)$ & 4250 & Not active & - & - & - \\
\hline $11 \mathrm{~b}(11 \sim 13)$ & 50.00 & Moderately active & - & - & - \\
\hline $14 \mathrm{~b}(14 \sim 17)$ & 60.00 & Moderately active & - & - & - \\
\hline $18 \mathrm{~b}(18 \sim 26)$ & 97.50 & Moderately active & - & - & Acetogenins \\
\hline $27 \mathrm{~b}(27 \sim 30)$ & 77.50 & Moderately active & - & - & Acetogenins \\
\hline $31 b(31 \sim 35)$ & 100.00 & Active & Inconsistent & Inconsistent & Acetogenins \\
\hline $35 b(35 \sim 36)$ & 100.00 & Active & Inconsistent & Inconsistent & Acetogenins \\
\hline $39 \mathrm{~b}(37 \sim 41)$ & 100.00 & Active & 15.3510 & 300.0588 & Acetogenins \\
\hline $44 \mathrm{~b}(42 \sim 44)$ & 100.00 & Active & 0.7460 & 34.3782 & Acetogenins \\
\hline $45 \mathrm{~b}(45 \sim 47)$ & 100.00 & Active & 1.0402 & 12.2466 & Acetogenins \\
\hline $48 b$ & 100.00 & Active & 2.0090 & 32.2041 & Acetogenins \\
\hline $49 \mathrm{~b}(49 \sim 56)$ & 100.00 & Active & 7.6875 & 47.2183 & Acetogenins \\
\hline $57 \mathrm{~b}(57 \sim 58)$ & 70.00 & Moderate active & - & - & - \\
\hline $61 \mathrm{~b}(59 \sim 62)$ & 42.50 & Not active & - & - & - \\
\hline
\end{tabular}

*Tested using phosphomolybdic acid solution 
Fractions with a mortality rate of at least $50 \%$ are considered moderately active, while $100 \%$ mortality is considered active. Fractions $2 b, 4 b$, $5 b, 6 b$, and $9 b 1$ were considered inactive for larvicidal activity while fraction $11 \mathrm{~b}, 14 \mathrm{~b}, 18 \mathrm{~b}$ and $27 \mathrm{~b}$ were considered moderately active with a minimum mortality rate of at least $50 \%$. These fractions had a light brownish colour compared to the previous fractions which were mostly oily yellowish fractions.

The colour became a darker brown as the fractions become more polar. Fractions $18 \mathrm{~b}$ and $27 \mathrm{~b}$ were suspected to be acetogenins as they exhibited a greyish blue colour on TLC plates in the phosphomolybdic acid test. The other fractions that were also suspected to be acetogenins were fractions $31 b, 35 b, 39 b, 44 b$, $45 \mathrm{~b}, 48 \mathrm{~b}$ and $49 \mathrm{~b}$ with mortality rates of $100 \%$. However, fractions $31 \mathrm{~b}$ and $35 \mathrm{~b}$ had $\mathrm{LC}_{50}$ values of more than $50 \mathrm{~g} / \mathrm{ml}$, whereas fractions $39 \mathrm{~b}, 44 \mathrm{~b}$, $45 \mathrm{~b}, 48 \mathrm{~b}$ and $49 \mathrm{~b}$ had a $\mathrm{LC}_{50}$ value less than $50 \mathrm{~g} / \mathrm{ml}$.

The most toxic fractions were $44 \mathrm{~b}$, with a $\mathrm{LC}_{50}$ value of 0.7460 , followed by $45 \mathrm{~b}$ with a $\mathrm{LC}_{50}$ value of 1.0402 . Fraction $57 \mathrm{~b}$ was moderately active while fraction $61 \mathrm{~b}$ was not active.
Fractions $15 \mathrm{a}, 16 \mathrm{a}$, and $18 \mathrm{a}$ had $\mathrm{LC}_{50}$ values of $2.2355,0.1110$ and $0.5050 \mathrm{~g} / \mathrm{ml}$, respectively.

\section{Identification of bioactive compound}

Fractions $44 \mathrm{~b}$ and $45 \mathrm{~b}$ which recorded the highest toxicity against Aedes aegypti mosquito larvae, appeared as white crystals, with a melting point of $65-67^{\circ} \mathrm{C}$ (Lit. $64-68^{\circ} \mathrm{C}$ ) [18]. They gave a greyish blue spot on the TLC plate when stained with phosphomolybdic acid solution which predicted an $\alpha, \beta$-unsaturated $\gamma$-lactone.

The bioactive compound was confirmed to be solamin by the IR (Figure 1) (carbonyl absorption at $1738 \mathrm{~cm}-1$ and $\mathrm{OH}$ groups at $3448 \mathrm{~cm}-1$ ) and 1H NMR (Figure 2). Solamin, a monotetrahydrofuran (mono-THF) $\gamma$-lactone acetogenin, was isolated and identified by Myint et al. [18] in 1991 (Figure 3).

Typical resonances of an $\alpha, \beta$-unsaturated $\gamma$ lactone [19] were observed in the $1 \mathrm{H}$ NMR spectrum: a doublet at $\delta 6.99$ (H33), a quartet of doublet at $\delta 4.99$ (H34) at the lactonic position, and a three-proton doublet at $\delta 1.41(\mathrm{Me}-35 / \mathrm{H} 35)$. It also exhibits a two-proton triplet at $\delta 2.25(\mathrm{H} 3)$, a two-proton multiplet at $\delta 3.41$ (H15 and H20) and a two-proton multiplet at $\delta 3.81$ (H16 and H19).

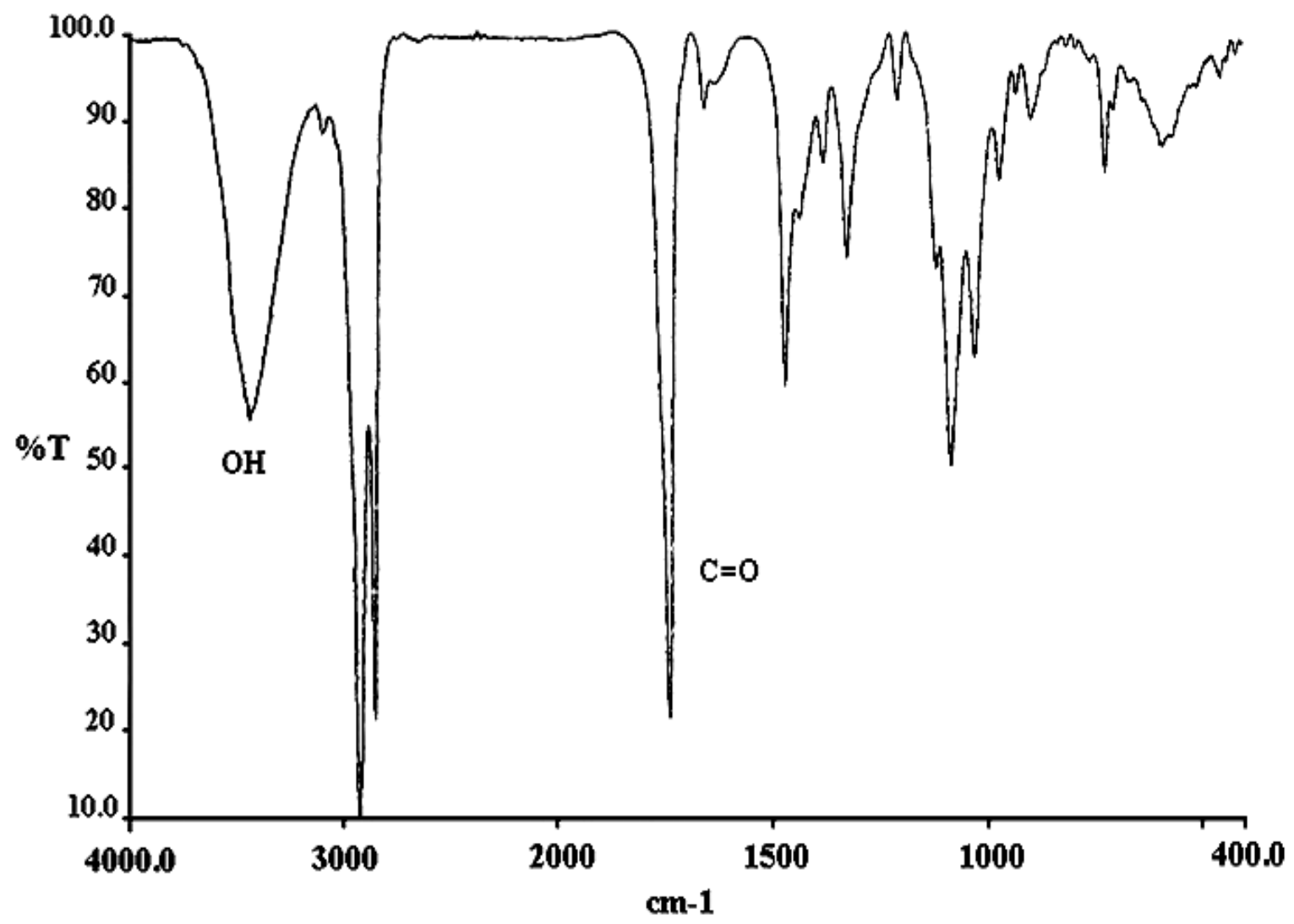

Figure 1: IR spectrum of solamin. 


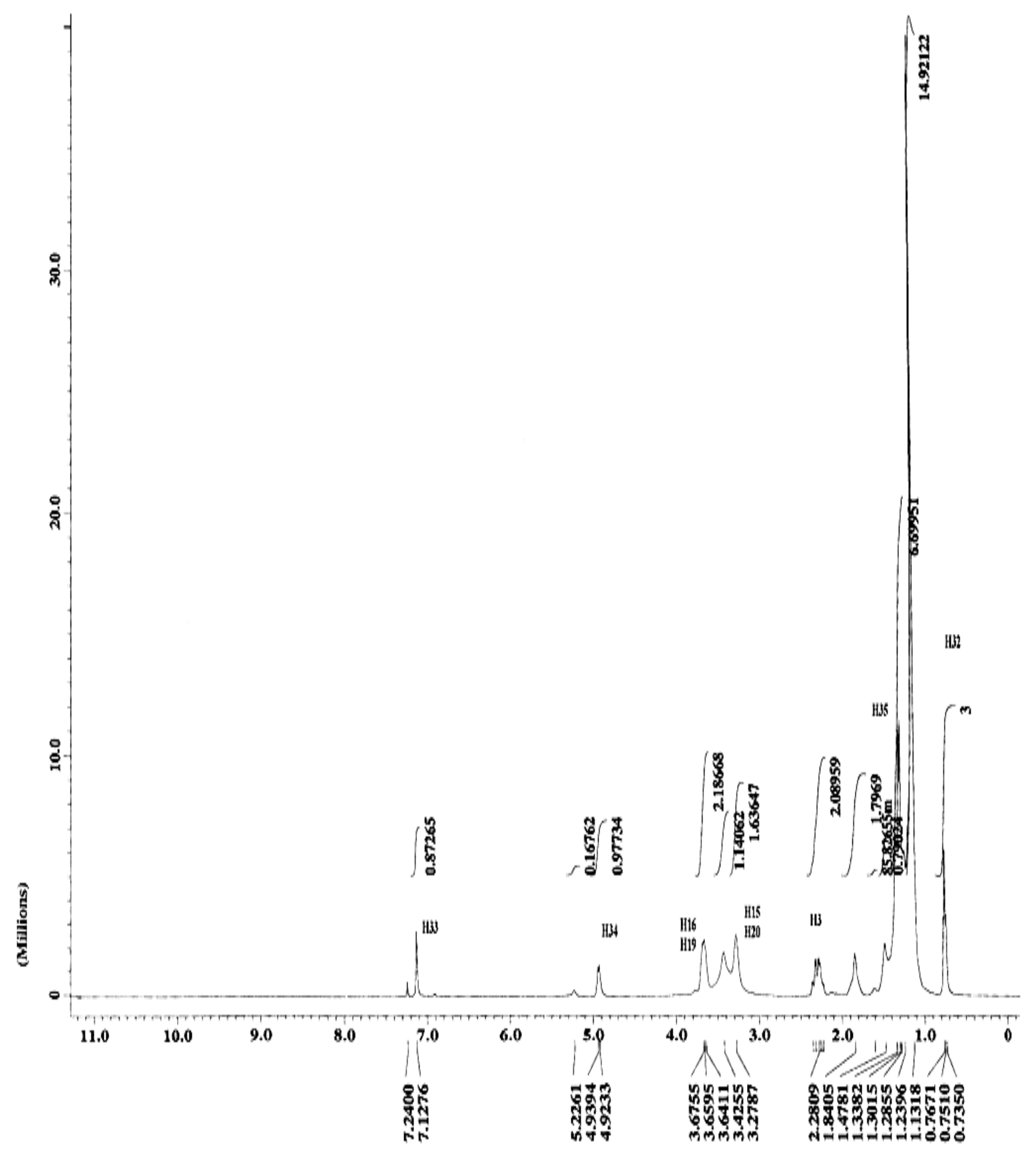

Figure 2: ${ }^{1} \mathrm{H}$ NMR spectrum of solamin (Fraction $\left.44 \mathrm{~b}\right)\left(100 \mathrm{MHz}, \mathrm{CDCl}_{3}\right.$ )

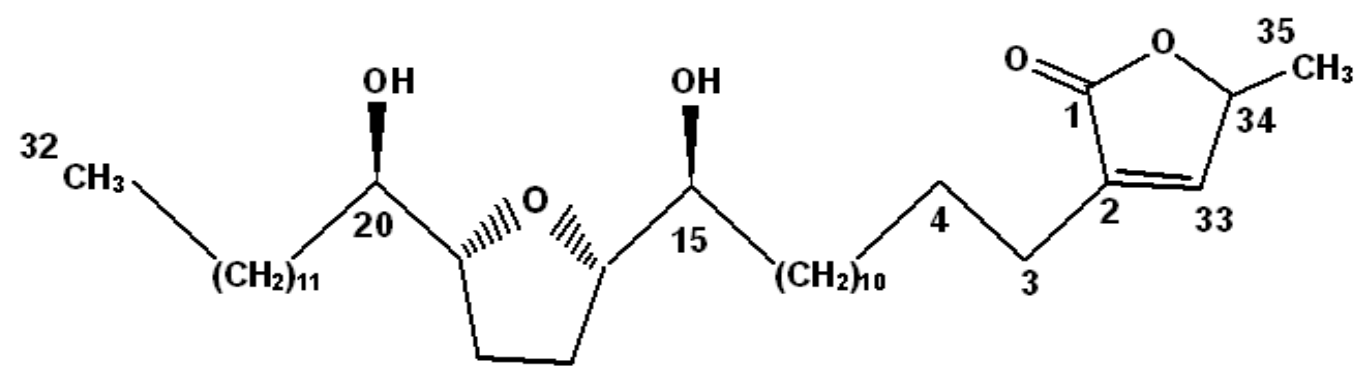

Figure 3: Structure of solamin [5] 


\section{Cytotoxicity assay}

The crude seed extracts of Annona muricata were bioassayed against brine shrimp (Artemia salina) using the [15] standard procedures with slight modifications. The crude hexane, chloroform and methanol extracts of Annona muricata were tested for cytotoxic activity. Table 3 below shows the results obtained from the bioassay tests.

The $\mathrm{LC}_{50}$ value of the hexane crude extract was $1399.2680 \mathrm{~g} / \mathrm{ml}$. This result showed that the toxicity level of the hexane crude was low or not toxic. For the chloroform extract, the $\mathrm{LC}_{50}$ value was $137.9022 \mathrm{~g} / \mathrm{ml}$ putting the extract's toxicity at the moderate toxicity level. The brine shrimps were very susceptible to the crude methanol extract with the $\mathrm{LC}_{50}$ value of $11.8823 \mathrm{~g} / \mathrm{ml}$.

Table 3: Cytotoxic activity of crude extracts in different solvent system

Solvent system $\quad \mathrm{LC}_{50}(\mathrm{~g} / \mathrm{ml})$

Hexane

1399.2680

Chloroform

137.9022

Methanol

11.8823

The $\mathrm{LC}_{50}$ value of the crude extracts showed that the brine shrimps were very susceptible to the methanol extract. Since both the methanol and chloroform extracts contained the bioactive acetogenin, it can be concluded that perhaps there were some other acetogenins in the methanol extracts that the brine shrimp were more susceptible to compared to the mosquito larvae.

This also showed that the isolated bioactive compound, solamin had a higher pesticidal or insecticidal effect rather than a cytotoxic effect. The acetogenins that were found in the methanol extracts may have a higher cytotoxic activity compared to the acetogenins found in the chloroform extracts.

Myint et al. [18] reviewed that the in vitro cytotoxic activity of solamin on the KB cells and VERO cells are not as high compared to other acetogenins from Annona muricata like murisolin, corrosolone, corossolin, annonacinone, and annonacin.

\section{Antimicrobial activities}

The Annona muricata seed extracts were tested for antimicrobial activity against Listeria monocytogenes, Vibrio parahaemolylicus, Escherichia coli and Pseudomonas aeruginosa. All crude extracts were not active against the bacteria with no inhibition zone (compared to the positive control of Ciprofloxacin).

The anti-microbial assay results showed that the Annona muricata crude extracts were inactive against the four types of bacteria, i.e. Listeria monocytogenes, Vibrio parahaemolylicus, Escherichia coli and Pseudomonas aeruginosa. To date, there is no literature stating exactly the micro-organisms that are susceptible to the Annona muricata extracts.

\section{CONCLUSION}

Evaluation of insecticidal properties was done on the seeds of Annona muricata that were pooled from various areas in Malaysia. The investigation revealed that medium to more polar extracts of Annona muricata seeds were strongly toxic to the Aedes aegypti larvae (chloroform extract $\mathrm{LC}_{50}$ value $0.9005 \mathrm{~g} / \mathrm{ml}$ and $\mathrm{LC}_{90}$ value $6.1776 \mathrm{~g} / \mathrm{ml}$ ) and brine shrimp (methanol extract $\mathrm{LC}_{50}$ value $11.8823 \mathrm{~g} / \mathrm{ml}$ ).

Fractions $44 \mathrm{~b}$ and $45 \mathrm{~b}$ of the chloroform extract showed strong toxicity towards the mosquito larvae with $\mathrm{LC}_{50}$ values of 0.7460 and $1.0402 \mathrm{~g} / \mathrm{ml}$, respectively. The bioactive compound was identified as solamin, an acetogenin compound. However, the extracts of Annona muricata were not anti-microbial.

\section{REFERENCES}


1. Kessler,P.J.A., (1993). Asian Annonaceae, a taxanomic and floristic challenge. In International Seminar and Workshop on the Taxanomy and Phytochemistry of the Annonaceae and Simaroubaceae, ed. R. Kiew, A.R. Ahmad and J. Anthonysamy, Universiti Pertanian Malaysia Library, Serdang, Malaysia, pp. 1-5

2. Wiart,C., (2000). Medicinal plants of Southeast Asia. Pelanduk Publications (M) Sdn Bhd, Malaysia, pp. 17

3. Abdul Hamid,A.H., (1993). Phytochemistry of Annonaceae in Malaysia. In International Seminar and Workshop on the Taxanomy and Phytochemistry of the Annonaceae and Simaroubaceae, ed. R. Kiew, A.R. Ahmad and J. Anthonysamy, Universiti Pertanian Malaysia Library, Serdang, Malaysia, pp. 1722

4. Kochummen,K.M., (1993). Ecological diversity of the Annonaceae in Malaysia. In International Seminar and Workshop on the Taxanomy and Phytochemistry of the Annonaceae and Simaroubaceae, ed. R. Kiew, A.R. Ahmad and J. Anthonysamy, Universiti Pertanian Malaysia Library, Serdang, Malaysia, pp. 6-8

5. Hisham,A., (1993). Annonaceous acetogenins: An overview. In International Seminar and Workshop on the Taxanomy and Phytochemistry of the Annonaceae and Simaroubaceae, ed. R. Kiew, A.R. Ahmad and J. Anthonysamy, Universiti Pertanian Malaysia Library, Serdang, Malaysia, pp. 2326

6. Alali,F.Q., Liu,X-X. and McLaughlin,J.L., (1998). Annonaceous acetogenins: Recent progress. J.Nat.Prod. 62, pp.504

7. Queiroz,E.F., Roblot,F., Serani,R., Laprevote,O. and Cavé,A., (1997). Spinencin, a new bis-tetrahydrofuran ring acetogenins from the seeds of Annona spinenscens. J.Nat.Prod. 60, pp.760

8. Liu,X.X., Pilarinou,E., and McLaughlin,J.L., (1999). Two novel acetogenins, annoglaxin and 27-hydroxybullatacin, from Annona glabra. J.Nat.Prod. 62, pp.848

9. Hui,Y.H., Rupprecht,J.K., Liu,Y.M., Anderson,J.E., Smith,D.L., Chang,C.J., and McLaughlin,J.L., (1989). Bullatacin and bullatacinone: two highly potent bioactive terminally acetogenins from Annona bullata. J.Nat.Prod. 52(3), pp.463
10. Gu,Z.M., Fang,X.P., Miesbauer,L.R., Smith,D.L., and McLaughlin,J.L., (1993). 30-31-and 32-hydroxybullatacinones: bioactive terminally hydroxylated annonaceous acetogenins from Annona bullata. J.Nat.Prod. 56, pp.870

11. Da Silva,E.L., Roblot,F., Mahuteau,J., and Cavé,A., (1997). Coriaheptocins A and B, the first heptahydroxylated acetogenins, isolated from roots of Annona coriacea. J.Nat.Prod. 60, pp.162

12. Da Silva,E.L., Roblot,F., Laprevote,O., Serani,L., and Cavé,A., (1997). Coriadienin, the first annonaceous acetogenins with two double bonds isolated from Annona coriacea. J.Nat.Prod. 59, pp.528

13. Hopp,D.C., Zeng,L., Gu,Z.M., Kozlowski,J.F., and McLaughlin,J.L., (1997). Novel mono-tetrahydrofuran ring acetogenins from the bark of Annona squamosa. J.Nat.Prod. 60, pp.581

14. WHO, (1981). Instruction for determining the susceptibility or resistance of mosquito larvae to insecticides, World Health Organisation Mimieograph WHO/VBC/81807

15. McLaughlin,J.L. and Rogers,L.L., (1998). The use of biological assays to evaluate botanicals. Drug Information Journal 32, pp. 513

16. Au,T.S., Yusof,M.Y., Wiart,c., Hassan,H., Hanifah,Y.A. and Kamaruddin,M.Y., (2003). Antibacterial activity of Annona squamosa Linnaeus (Annonaceae). In Investing in Innovation 2003, Vol 3:Bioscience and Biotechnology, ed. M.A. Hassan et al., Universiti Putra Malaysia Press, Serdang, Selangor, Malaysia, pp. 7-10

17. Promsiri,S., Naksathit,A., Kruatrachue,M., and Thavara,U. (2006). Evaluation of larvicidal activity of medicinal plant extracts to Aedes aegypti (Diptera:Culicidae) and other effects on a non target fish. Insect Science. 13(3), pp.179

18. Myint,S.H., Cortes,D., Laurens,A., Hocquemiller,R., Lebœuf,M., Cavé,A., Cotte,J. and Quéro,A.M., (1991). Solamin, a cytotoxic mono-tetrahydrofuranic $\gamma$-lactone acetogenin from Annona muricata seeds. Phytochem. 30, pp. 3335

19. Jolad,S.D., Hoffmann,J.J., Schram,K.H., Cole,J.R., Tempesta,M.S., Kriek,G.R. and Bates,R.B., (1982). Uvaricin, a new antitumor agent from Uvaria accuminata (annonaceae). J.Org.Chem. 47, pp. 3151 